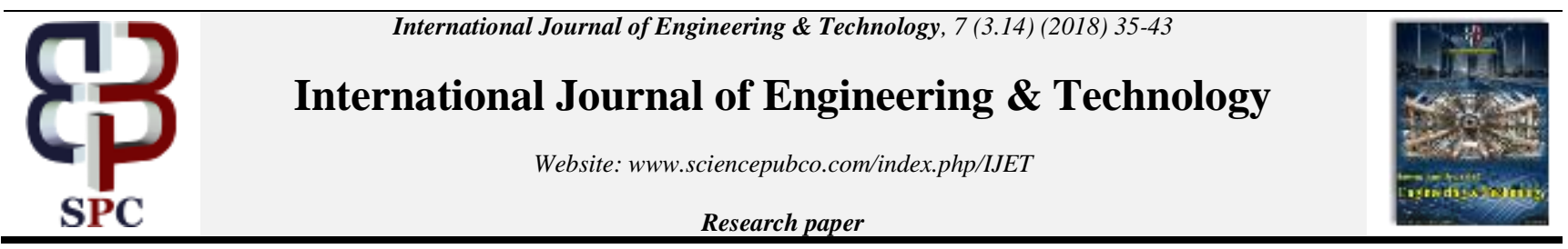

\title{
Impact of Hydrological Study to Water Quality Status in Kuantan River, Pahang, Malaysia
}

\author{
Frankie Marcus Ata ${ }^{1}$, Mohd Khairul Amri Kamarudin ${ }^{1,2^{*}}$, Nadzifah Yaakub ${ }^{3}$, Noorjima Abd. Wahab ${ }^{1}$, Mohd \\ Ekhwan Toriman ${ }^{4}$, Hafizan Juahir ${ }^{1}$, Muhammad Barzani Gasim ${ }^{1}$, Sunardi ${ }^{5}$, Aishatul Amiera Abdul Halim ${ }^{3}$, \\ Muhammad Nizam Adha Abd Raoff ${ }^{3}$, Muhamad Najmi Haris ${ }^{3}$ \\ ${ }^{I}$ East Coast Environmental Research Institute (ESERI), Universiti Sultan Zainal Abidin, Gong Badak Campus, 21300 Kuala Nerus, Ma- \\ laysia \\ ${ }^{2}$ Faculty of Applied Social Science, Universiti Sultan Zainal Abidin, Gong Badak Campus, 21300 Kuala Nerus, Malaysia \\ ${ }^{3}$ Faculty of Bioresources and Food Industry, Universiti Sultan Zainal Abidin, Besut Campus, 22000 Besut, Terengganu, Malaysia \\ ${ }^{4}$ Faculty of Social Sciences and Humanities, Universiti Kebangsaan Malaysia, 43600, Bangi, Selangor, Malaysia \\ ${ }^{5}$ Postgraduate Program on Environmental Science, Universitas Padjadjaran, Indonesia \\ *Corresponding author E-mail: mkhairulamri@unisza.edu.my
}

\begin{abstract}
Water is a vital for all aspects of human and ecosystem survival. The evaluations of water quality parameters and hydrological status are necessary to enhance the performance of an assessment operation and develop better water resources management and plan. There are three sampling stations were selected along the Kuantan River. Seven water quality parameters were measured and Malaysian Department of Environment Water Quality Index (DOE-WQI) was calculated and classified based on the National Water Quality Standard, Malaysia (INWQS). The water balance status applied to determine the stability of inflows and outflows into and from the basin. As a result, all water quality parameters (DO, COD, BOD, TSS, $\mathrm{NH}_{3}{ }^{-} \mathrm{N}$ and $\mathrm{pH}$ ) which categorized under the ranged of class II until class IV respectively. Kuantan River located in Pahang state, Malaysia which is significantly degrading due to human activities as well as urbanization in and within the area. Overall, the result showed that the estimated average sediment that flows out of Kuantan Rivers is 108.88tonnes/day (24 February 2017) and 44.917 tonnes/day (30 April 2017). The contributors of sedimentation problems in Kuantan River are from unsustainable land use such as urbanization and industrialization which trapping the bed sediments and river band erosion.
\end{abstract}

Keywords: Hydrological and water quality status; Kuantan River; National Water Quality Standard (NWQS); Sedimentation

\section{Introduction}

Rivers have played a vital part in the world. Rivers an important role throughout the history in the development of human civilization and as life-sustaining role in human societies such as source of water, food, transportation, recreation, industrial, tourism, farming, agriculture, hydroelectricity and disposing of waste [1-2]. The hydrological properties of water bodies will be beneficial to Kuantan River and will make it possible to develop and manage the river in the environmental sustainable method.

Every year, Kuantan part of the Pahang state has been affected by problem related to flooding and water quality deterioration. The effects of flooding in Kuantan area were dislocation from their place and also the government and private sector properties have been damaged which caused the negative impact on economy and sociality. The role of river within the global hydrologic cycle or hydrological system depends for their very existence upon a balance between their many sources of water, anthropogenic factors and changes of climate [3-5]. The water balance of river is im- portant enough to have warranted considerable study throughout the world. The river system possessing its own hydrologic system including the restrictions on water utilization, especially during wet season and dry season to enhance the water quality management activities.

The Principles of Hydrology section, water balance is the concept used to understand the availability of water resources in hydrological systems which are the inflows and outflows into and from the basin. In the natural environment, water is almost constantly in motion and has ability to change state from liquid to a solid or a vapor under appropriate conditions. The rivers and streams can be subjected to regulation by well-established practices through the use of dams, storage reservoirs, and diversions. It is mainly through these controls that efforts are made to make the most efficient usage of water as a resource Fig. 1 showed the conservation of mass within a specific area over a specific period of time and water inflows are equal to water outflows, plus or minus any change of storage within the area of interest. 


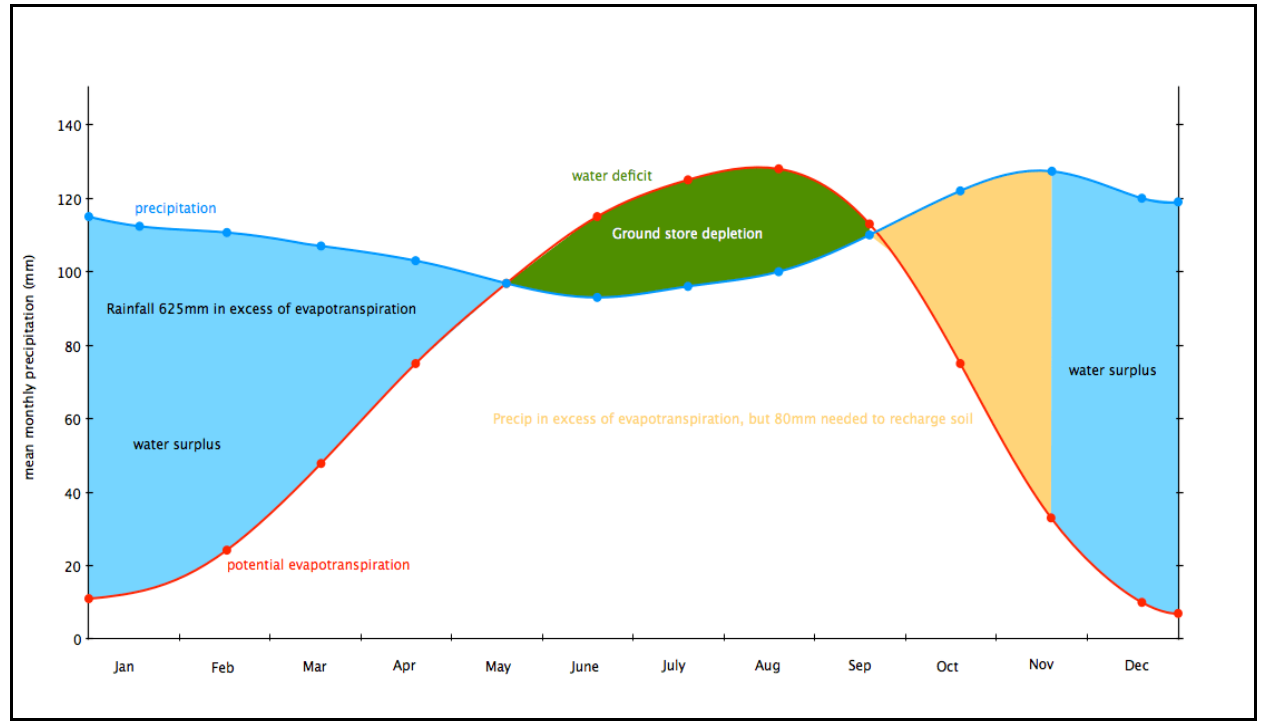

Fig. 1: The Principles of hydrology on water balance concept

\section{Methodology}

A research on the hydrological and water quality of Kuantan River was carried out in order to examine the existing physical environment problems during the study period from February 2017 until April 2017.Kuantan River is in the district of Kuantan at the north eastern end of Pahang State, Peninsular Malaysia. It is one of the important river basins in Pahang and covered $1630 \mathrm{~km}^{2}$ of catchment area which started from forest reserved area in Ulu Kuantan District towards the South China Sea. It consists of several tributaries and these rivers in the major rural, agricultural, urbanization and industrial areas of Kuantan District and flow out into South China Sea. Kuantan is considered a social, economic and commercial Centre for the East Coast of Peninsular Malaysia due to its strategic location and the rapid development which has transformed and modernized city.

All the samples were collected at Pengorak River, Karang River and Balok River (Table 1 and Fig. 2). These tributaries rivers were located near to the Gebeng Industrial site and tourism areas in Kuantan. The river flows pass through the wide industrial facilities which include steel industries, palm oil mills and pipe coating and others development activities. Besides that, these three rivers are located near the Kuantan Port which is temporary storage of bauxite mining for mineral processing. The future development was identified and triggered Kuantan as a city for trade, commerce, transportation, tourism and industrialization in the East Coast of Peninsular Malaysia.

Table 1: Location of Sampling Station at the Kuantan River, Pahang, Malaysia

\begin{tabular}{|c|c|c|}
\hline $\begin{array}{c}\text { Sampling } \\
\text { Station }\end{array}$ & Latitude & Longitude \\
\hline $\begin{array}{c}\text { Pengorak } \\
\text { River }\end{array}$ & $03^{\circ} 58^{\prime} 8.937^{\prime \prime} \mathrm{N}$ & $103^{\circ} 24^{\prime} 36.352^{\prime \prime} \mathrm{E}$ \\
\hline $\begin{array}{c}\text { Karang } \\
\text { River }\end{array}$ & $03^{\circ} 53^{\prime} 54.751^{\prime \prime} \mathrm{N}$ & $103^{\circ} 21^{\prime} 49.803^{\prime \prime} \mathrm{E}$ \\
\hline $\begin{array}{c}\text { Balok } \\
\text { River }\end{array}$ & $03^{\circ} 56^{\prime} 32.274^{\prime \prime} \mathrm{N}$ & $103^{\circ} 22^{\prime} 20.229^{\prime \prime} \mathrm{E}$ \\
\hline
\end{tabular}

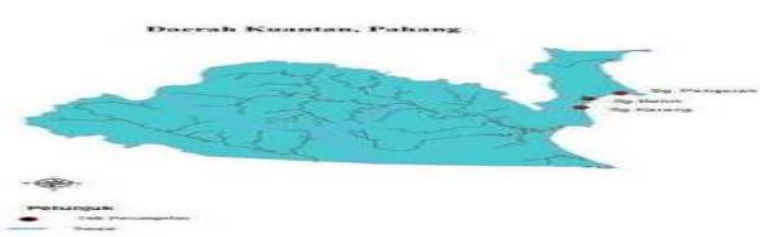

Fig. 2: The location of sampling Station at Kuantan River, Pahang, Malaysia

\subsection{Sampling Procedure}

Global Positioning System (GPS) was used to determine the coordinate of sampling stations and to clarify the location of sampling stations during the sampling periods. This study involves three main sampling stations which located around Kuantan River. The Current Meter was measured using flow meter (model FP101) and a Bushnell 850 Laser Range Finder and Depthmate Sounder was used to measure the width and depth of river and the velocity of water. Fig. 3 showed the hydrology theoretical of discharge measurement depends on the flow velocity measurement. (Equation (1), Equation (2) and Equation (3)) used in the estimation of the cross section geometry section using the depth, width and velocity measurement and the discharge value $(\mathrm{Q})$ is the product of velocity and cross section area (A) [6].

Cross section area (A)

$\mathrm{A}=\mathrm{dw}(\mathrm{m})$ or $\mathrm{A}=1 / 2 \mathrm{dw}(\mathrm{m})$

$\sum \mathrm{A} 1+\mathrm{A} 2+\mathrm{A} 3+\mathrm{A} 4$

Discharge value (Q):

$\mathrm{Q}=\mathrm{vA}$, or $\mathrm{Q}=1 / 2 \mathrm{vA}$

$\mathrm{Q}=\mathrm{m}^{3} \mathrm{sec}^{-1}$

To obtain the unit $\mathrm{L} \mathrm{day}^{-1}$, the following formula is used:

$\mathrm{Q}=\mathrm{m}^{3} \mathrm{sec}^{-1} \times 86400 \mathrm{sec} \mathrm{day}^{-1} \times 1000 \mathrm{~L} \mathrm{~m}^{-3}$

$=\mathrm{L}_{\text {day }}{ }^{-1}$

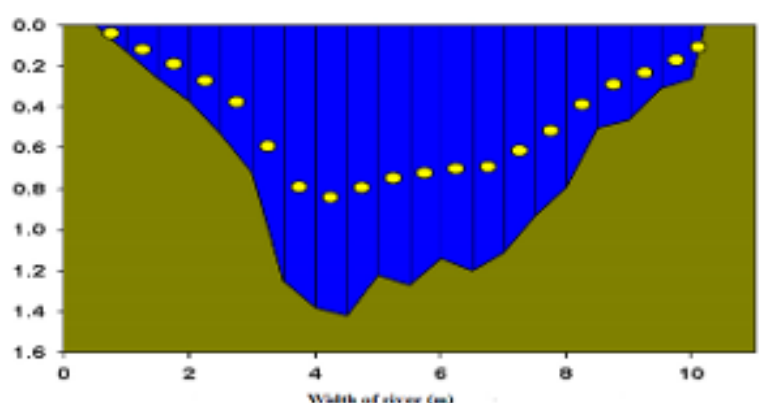

Fig. 3: The theoretical of discharge measurement by cross section of the river

One-liter sample of surface water was collected about $10 \mathrm{~cm}$ below the surface using HDPE bottle $(500 \mathrm{ml})$ for measuring their concentration using standard laboratory methods United States 
Environmental Protection Agency (USEPA) Methods. The measurements of in situ parameters were Dissolved Oxygen (DO), Biochemical Oxygen Demand (BOD), pH, Ammoniacal Nitrogen $\left(\mathrm{NH}_{3}{ }^{-} \mathrm{N}\right)$ and Turbidity (TUR). All of these parameters were determined by using the water-quality Multiprobe Model DO Meter YSI 58, BOD Check Meter and Turbidity Meter. Thesemultiprobe meter was calibrated before field sampling. Water samples were analyzed in the laboratory to determine two water quality parameters which are Total Suspended Solid (TSS) and Chemical Oxygen Demand (COD) [7-9]. TSS was measured using filtration methods with membrane filter $45 \mathrm{~mm}$ and vacuum pump (Gravimetric Method) (Fig. 4).

TSS is described the concentration of solid-phase material suspended in a water sediment mixture which usually expressed in milligrams per liter (mg/L) [10-11]. The precisely precaution steps should be taken when the river water sample were taken. Interference of the river water flow should be minimum to avoid deposition of the measured suspended sediment $[8,12,13]$. The readings of TSS were taken and calculated using the (Equation (4)). Then, the COD test (Methods for Chemical Analysis of Water and Waste, EPA -600/4-79-020, USEPA, Method 410.1) is commonly used to indirectly measure the amount of organic compounds in water. All samples were labelled and preserved using acid nitric and stored in an icebox and transported to the laboratory for analysis within 48 hours.

$\mathrm{TSS}=\{(\mathrm{WBF}+\mathrm{DR})-\mathrm{WBF}\}(\mathrm{mg}) \times 1000 / \mathrm{VFW}(\mathrm{mL})$ $=\mathrm{mg} / \mathrm{L}$

$* \mathrm{WBF}=$ Weight of membrane filter; $\mathrm{DR}=$ Dry residue; VFW $=$ Volume of filtered water

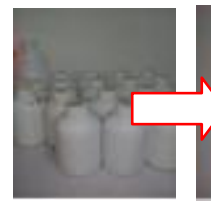

(a)

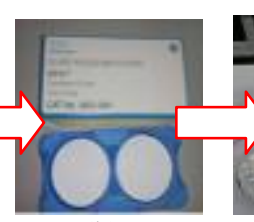

(b)

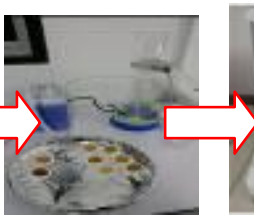

(c)

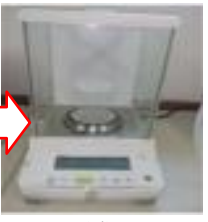

(d)
Fig. 4. a) Sample water b) Membrane filter c) Filtration apparatus connected to a vacuum pump d) Electronic weighing

\subsection{Water Balance Procedure}

Detail hydrological balance conditions are discussed below. The climatological data were obtained from Batu Embun Climatological Station with permission from Malaysian Meteorological Department (MMD). In this study, the monthly rainfall data from 2000 - 2017 were abstracted directly from the climatological records whiles the potential evapotranspiration (PE) and runoff (r) were calculated using the (Equations (5)). Evapotranspiration (PE) is a critical hydrological link between the earth's surface and the atmosphere. It is commonly defined as the loss of water from a given area during a specified time by evaporation from the soil surface and by transpiration from plants. The Thornwaite method expression for $P E$ is the most successful and has been widely used. Data obtained from the historical records and compute data were then used to estimate the average water balance of the river [14-16]. By presuming that inflow waters were derived from direct and indirect rainfalls to the lake and outflow waters through evaporation and runoff to the Kuantan River. The Thornwaite equation is expressed by:

$$
P \cdot E_{x}=0.63 N \quad 10\left(\frac{t_{c}^{a}}{\frac{m m}{L}}\right)
$$

Where $\mathrm{PE}=$ Monthly Evapotranspiration $(\mathrm{mm}), \mathrm{N}=$ Length of day based on $\mathrm{N}$ factor $(0.25)$, $\mathrm{tc}=$ Time of concentration, $1=$ Heat index and $\mathrm{a}=$ the location-dependent coefficient.

\subsection{Water Quality Analysis}

The primary method employed to classify the river water quality monitored by National Water Quality Standard (NWQS), which a set of standards derived based on beneficial uses of water. The DO concentration can drop below essential level due to the pollution caused either by geomorphology and anthropogenic factors. The plant and aquatic organisms are highly dependent on the DO concentration. BOD is an amount of oxygen needed to oxidize the organic matter in a water body. The high amounts of pollutants such as pesticide, fertilizers and others nutrients can increase the BOD concentration. Oxygen used in the decomposition process robs the other oxygen that used by aquatic organisms to live [1719]. COD is used as a measure of the oxygen equivalent of the organic matter content of a sample that is susceptible to oxidation by a strong chemical oxidant. COD used to measure the pollutant load in the water body and can related to BOD, organic matter and organic carbon.

Ammoniacal nitrogen $\left(\mathrm{NH}_{3}{ }^{-} \mathrm{N}\right)$, is a measure for the amount of ammonia which indicates nutrient status found in waste products, such as sewage, liquid manure and other liquid organic waste products from industrial, agricultural and farming areas. $\mathrm{NH}_{3}{ }^{-} \mathrm{N}$ used as monitoring tools of the health of water in natural bodies such as rivers or lakes. If higher concentration of ammonia nitrogen recorded, then the river or lake water considered as polluted [20-22]. The higher level of turbidity can interfere with disinfection and provide a medium for microbial growth. Turbidity can be effectively used as an indicator of total phosphorus and suspended solids concentrations in streams [19,23]. The $\mathrm{pH}$ is the measure of the acidity of river water. The $\mathrm{pH}$ scale commonly ranges from 0 to 14 and this scale is not linear but rather it is logarithmic. The distilled water is said to be neutral, with a $\mathrm{pH}$ of 7 . The water with a $\mathrm{pH}$ below 7.0 is considered acidic, while water with $\mathrm{pH}$ greater than 7.0 is considered basic or alkaline [21].

Table 2 showed the NWQS for Malaysia and as a one of tool to evaluate the water quality of the Kuantan River included the possible sources from anthropogenic activities which influenced the water quality were also given. Based on DOE scale classifies the water quality as 'clean', 'slightly polluted' and 'polluted'.

Table 2: National Water Quality Standards (NWQS) for Malaysia (DOE 2008)

\begin{tabular}{|c|c|c|c|c|c|c|}
\hline \multicolumn{4}{|c|}{ Parameter } & \multicolumn{3}{|c|}{ Class } \\
\hline & Unit & I & II & III & IV & V \\
\hline $\begin{array}{l}\text { Ammoniacal } \\
\text { Nitrogen }\left(\mathrm{NH}_{3}{ }^{-}\right. \\
\mathrm{N}) \\
\end{array}$ & $\mathrm{mg} / \mathrm{L}$ & $<0.1$ & $\begin{array}{c}0.1- \\
0.3\end{array}$ & $\begin{array}{c}0.3- \\
0.9\end{array}$ & $\begin{array}{c}0.9- \\
2.7\end{array}$ & $>2.7$ \\
\hline $\begin{array}{l}\text { Biochemical } \\
\text { Oxygen De- } \\
\text { mand (BOD) }\end{array}$ & $\mathrm{mg} / \mathrm{L}$ & $<1$ & $1-3$ & $3-6$ & $\begin{array}{l}6- \\
12\end{array}$ & $>12$ \\
\hline $\begin{array}{l}\text { Chemical Oxy- } \\
\text { gen Demand } \\
\text { (COD) }\end{array}$ & $\mathrm{mg} / \mathrm{L}$ & $<10$ & $\begin{array}{c}10- \\
25\end{array}$ & $25-50$ & $\begin{array}{l}50- \\
100\end{array}$ & $>100$ \\
\hline $\begin{array}{c}\text { Dissolved } \\
\text { Oxygen (DO) }\end{array}$ & $\mathrm{mg} / \mathrm{L}$ & $>7$ & $5-7$ & $3-5$ & $1-3$ & $<1$ \\
\hline $\mathrm{pH}$ & - & $>7$ & $6-7$ & $5-6$ & $<5$ & $>5$ \\
\hline TSS & $\mathrm{mg} / \mathrm{L}$ & $<25$ & $\begin{array}{c}25- \\
30\end{array}$ & $\begin{array}{l}50- \\
150 \\
\end{array}$ & $\begin{array}{c}150- \\
300\end{array}$ & $>300$ \\
\hline $\begin{array}{l}\text { Water Quality } \\
\text { Index (WQI) }\end{array}$ & - & $<92.7$ & $\begin{array}{c}76.5 \\
- \\
92.7 \\
\end{array}$ & $\begin{array}{c}51.9- \\
76.5\end{array}$ & $\begin{array}{c}31.0 \\
- \\
51.9\end{array}$ & $>31.0$ \\
\hline \multirow[t]{3}{*}{ Class I } & \multicolumn{6}{|c|}{ Conservation of natural environment } \\
\hline & \multicolumn{6}{|c|}{ Water supply I - Practically no treatment necessary } \\
\hline & \multicolumn{6}{|c|}{ Fishery I - Very sensitive aquatic species } \\
\hline \multirow[t]{2}{*}{ Class IIA } & \multicolumn{6}{|c|}{ Water supply II - Conventional treatment required } \\
\hline & \multicolumn{6}{|c|}{ Fishery II - Sensitive aquatic species } \\
\hline Class IIB & \multicolumn{6}{|c|}{ Recreational use with body contact } \\
\hline \multirow[t]{2}{*}{ Class III } & \multicolumn{6}{|c|}{ Water supply III - Extensive treatment required } \\
\hline & \multicolumn{6}{|c|}{$\begin{array}{l}\text { Fishery III - Common of economic value and tolerant spe- } \\
\text { cies; livestock drinking }\end{array}$} \\
\hline Class IV & \multicolumn{6}{|c|}{ Irrigation } \\
\hline Class V & \multicolumn{6}{|c|}{ None of the above } \\
\hline
\end{tabular}




\section{Results and Discussion}

\subsection{Hydrology and Climatology Status}

Hydrological analysis was carried out to evaluate the water level characteristics of the water body as well as the drainage systems.

From the secondary findings from MMD (Batu Embun Station, Pahang, Malaysia) proved that the total annual rainfall distribution trends ranged $1684.8 \mathrm{~mm}$ (2002) to $2606.5 \mathrm{~mm}$ (2008) every year from 2000 until 2016 (Fig. 5).

The secondary findings indicate that the trend in the study area has significant changes in water quality level. During this season, the study area could be considered as the wettest region since all rainfall indices tested are higher than in other neighbouring state of the Peninsular. Malaysia is one of countries receive are average rainfall of more than $1500 \mathrm{~mm}$ per annum.

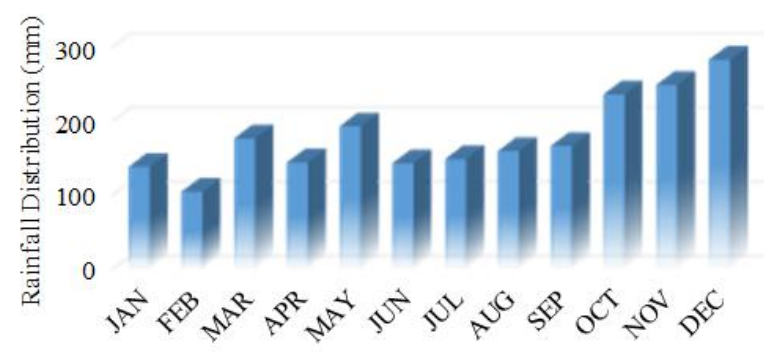

Months (2000 - 2016)

Fig. 5: Rainfall distribution at Batu Embun Station, Pahang, Malaysia, $2000-2016$

Fig. 6 showed the trend analysis that has been conducted in Pahang River Basin with more than 10 years of rainfall data from 1970 to 2014, the annual maximum rainfall with the highest maximum rainfall occurrence in years 1988 about range in $158.80 \mathrm{~mm}$. Meanwhile, the lowest minimum rainfall shows in 1974 about

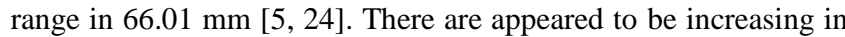
trend throughout 45 years in Pahang River Basin, Pahang, Malaysia.

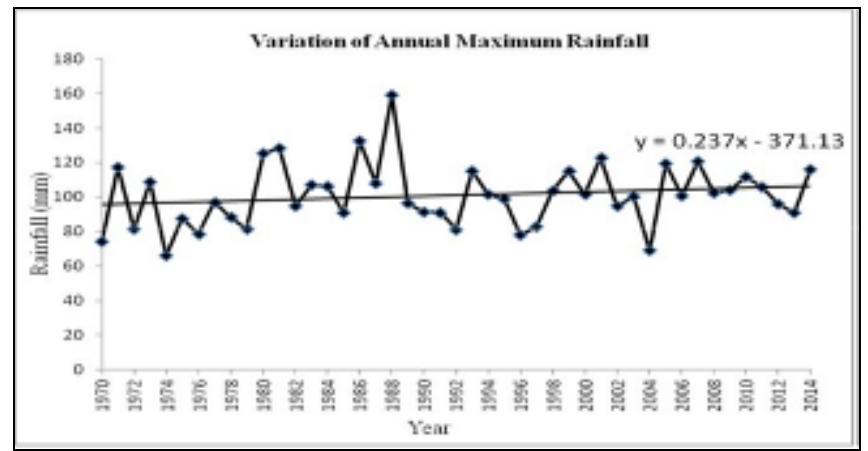

Fig. 6: Annual maximum rainfall in 45 years, Pahang River Basin, Pahang, Malaysia

Fig. 7 showed the records of numbers of rain days at Batu Embun Station from 2000 until 2016, the total annual rainy days ranged from 142 days (2015) to 203 days (2003) with an average of 182 days (February) to 354 days (November).

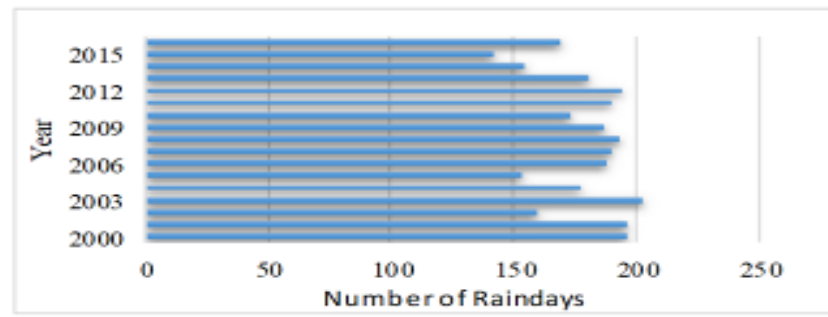

Fig. 7: Records of numbers of rain days at Batu Embun Station, Pahang, Malaysia, 2010 - 2016

The highest total number of rainy days were obtained at on November until December every year. The factors that caused water quality deterioration will affect by the hydrological cycle, biological cycles, global biogeochemistry, biodiversity and ecosystem. Increased in the velocity and volume of water will also increase the rate of the erosion and this situation will increase the amount of suspended solid, water turbidity the river and the river became more shallow, give negative impact on the benthic ecosystem and the flora and fauna in the area around this river and reducing the water quality [19, 25-26]. The hydrological in Kuantan River is also effected by the intertidal monsoon seasons. The increased of velocity and flow of water river will brings the high loads of TSS as well as other contaminants. The adverse effects due to the hydrological and water quality changes include damage to the plant communities and aquatic ecosystems.

Through the long-term research on changes in amount production of suspended sediment concentration load, river discharge level and taking into the weather variable caused by changes in climates but this research only covered two months (24 February 2017 until 30 April 2017). The amount suspended sediment production in a river basin is a complex problem in tropical areas as soil erosion, hydrological and geomorphology factors due to the very high rainfall contributes to it especially during the unbalance climates around the catchment areas. In the normal follow by the hydrological theory, where the discharge value $(\mathrm{Q})$ in the elevated downstream is higher than the upstream but in Table 3 showed the discharge value (Q) at Balok River at the downstream Kuantan River showed the highest values at $66.63 \mathrm{~m}^{3} / \mathrm{s}$ (24 February) and 65.41 $\mathrm{m}^{3} / \mathrm{s}$ (30 April), the lowest values at Pengorak River with 14.90 $\mathrm{m}^{3} / \mathrm{s}$ (24 February) and $14.62 \mathrm{~m}^{3} / \mathrm{s}$ (30 April) which at the upstream Kuantan River. The daily suspended sediment production was calculated to estimate the TSS tonnes per day (tonnes/day). The highest daily suspended sediment production in a river basin (Kuantan River) was caused by highest discharge value and the highest TSS, the highest value of estimated TSS (tonne/day) or suspended sediment load at Balok River (24 February), 302.00 tonnes/day and 102.969 tonnes/day at Karang River (30 April). It is because the data on 24 February at Balok River were collected after the rainfall happened. In the normal reading through the hydrological theory, where the discharge value $(\mathrm{Q})$ or water velocity in the elevated downstream is higher than upstream and the TSS production higher during the water flow in a basin increased because the higher flow contains the strong energy to move the higher concentrated the suspended sediment load compared to the low flow.

Table 3: Estimated Suspended Load in the Kuantan River Basin, Pahang, Malaysia

\begin{tabular}{|c|c|c|c|c|}
\hline Station & \multicolumn{2}{|c|}{ Estimated Q (L/day) } & \multicolumn{2}{c|}{$\begin{array}{c}\text { Estimated TSS tonnes } \\
\text { per day (tonnes/day) }\end{array}$} \\
\hline & $24 / 02 / 2017$ & $\begin{array}{c}30 / 04 / \\
2017\end{array}$ & $\begin{array}{c}24 / 02 / \\
2017\end{array}$ & $\begin{array}{c}30 / 04 / \\
2017\end{array}$ \\
\hline $\begin{array}{c}\text { Pengorak } \\
\text { River }\end{array}$ & $872,640,000$ & $1,263,168,000$ & 44.129 & 28.699 \\
\hline $\begin{array}{c}\text { Sungai } \\
\text { Karang }\end{array}$ & $1,287,360,000$ & $5,651,424,000$ & 26.699 & 102.969 \\
\hline $\begin{array}{c}\text { Sungai } \\
\text { Balok }\end{array}$ & $5,756,832,000$ & $870,048,000$ & 302.00 & 9.571 \\
\hline Purata & $2,638,944,000$ & $2,594,880,000$ & 108.88 & 44.917 \\
\hline
\end{tabular}


Water balance estimation is an important tool to assess the current status and trends in water resource availability in an area over a specific period of time. Furthermore, water balance estimates strengthen water management decision making, by assessing and improving the validity of visions, scenarios and strategies. Water balance is the most important integral physiographic characteristic of any territory which is determines its specific climate features, typical landscapes and opportunities for human land use. Assessment of mean long-term water balances of large regions at a sufficient accuracy depends on reliable estimation of the major water balance components such as rainfall intensity, evaporation and runoff.

Mean monthly rainfall value of the Batu Embun for 17 years (2000 to 2016) was used to determine runoff value by extracting monthly evapotranspiration from monthly rainfall. For the 17 years' period, monthly rainfall ranged from $104.5 \mathrm{~mm}$ (February) to $283 \mathrm{~mm}$ (December). Range of monthly temperature varied from 25.7 to 27.7, in which May was the highest and January the lowest. Evapotranspiration values derived through the model ranged from 5.4 to $3.6 \mathrm{~mm} /$ day or at a percentage range from $0.5 \%$ to $6.5 \%$, with April showing the highest value and December with the lowest. Runoff values for the study area based on rainfall minus evapotranspiration of the Batu Embun Station ranged from 99.3 to $279.4 \mathrm{~mm}$ with February and November having the highest runoff. This trend is closely related with the annual monsoon season (Table 4). It is advisable to the contractor whom involved in land disturbance to avoid development during this particular event.

Table 4: Water balance values for Pahang (Batu Embun Station, Pahang, Malaysia) for the period from 2000 to 2017

\begin{tabular}{|c|c|c|c|c|c|c|}
\multicolumn{2}{|c|}{ Malaysia) for the period from 2000 to 2017} \\
Month & $\begin{array}{c}\text { Evapo- } \\
\text { transpiration } \\
(\text { ET) }\end{array}$ & $\%$ & $\begin{array}{c}\text { Runoff } \\
(\mathrm{r})\end{array}$ & $\%$ & $\begin{array}{c}\text { Rainfall } \\
(\mathrm{P}) \\
(\mathrm{mm})\end{array}$ & $\%$ \\
\hline Jan & 4 & 2.89 & 134.4 & 97.11 & 138.4 & 100 \\
\hline Feb & 5.2 & 4.98 & 99.3 & 95.02 & 104.5 & 100 \\
\hline March & 5.2 & 2.95 & 171.2 & 97.05 & 176.4 & 100 \\
\hline Apr & 5.4 & 3.74 & 138.8 & 96.26 & 144.2 & 100 \\
\hline May & 4.8 & 2.49 & 188 & 97.51 & 192.8 & 100 \\
\hline June & 4.6 & 3.22 & 138.4 & 96.78 & 143 & 100 \\
\hline July & 4.5 & 3.02 & 144.3 & 96.98 & 148.8 & 100 \\
\hline August & 4.7 & 2.94 & 154.9 & 97.06 & 159.6 & 100 \\
\hline Sept & 4.6 & 2.76 & 161.8 & 97.24 & 166.4 & 100 \\
\hline Oct & 4.1 & 1.74 & 231.7 & 98.26 & 235.8 & 100 \\
\hline Nov & 3.8 & 1.53 & 245.1 & 98.47 & 248.9 & 100 \\
\hline Dec & 3.6 & 1.27 & 279.4 & 98.73 & 283 & 100 \\
\hline Total & 54.5 & 33.54 & 2087.3 & 1166.46 & 2141.8 & 1200 \\
\hline
\end{tabular}

\subsection{Water Quality Status}

Changes in water quality of river are strongly related to surroundings areas activities and the types of land use to determine the kinds and amounts of contaminants that flow into river. The water quality parameters from the sampling stations could provide useful information on land use activities within the river catchment. $\mathrm{NH}_{3}$ $\mathrm{N}$, TUR, TSS, COD, BOD, DO and $\mathrm{pH}$ were chosen to show their relation to human activities as well as to river discharge (Q). All the parameters which comprised of parameters were analyzed in accordance to the American Public Health and Association (APHA) standard methods for water and wastewater.

\subsubsection{Ammonia Cal Nitrogen $\left(\mathrm{NH}_{3}{ }^{-} \mathrm{N}\right)$ Concentration}

The ammonia nitrogen content in Kuantan River is 0.99 to 2.03 $\mathrm{mg} / \mathrm{L}$ (24 February) and 1.4 to $2.3 \mathrm{mg} / \mathrm{L}$ (30 April) (Fig. 8). The average ammonia nitrogen concentrations in all stations were classified as Class IV of the NQWS classification. The higher concentration at Balok River and Pengorak River compared Karang River because is near the wet market and industrial area respectively. According NWQS, the maximum threshold level of $\mathrm{NH}_{3}{ }^{-} \mathrm{N}$ for Malaysian rivers which support aquatic life is $0.9 \mathrm{mg} / \mathrm{L}$. At all events, higher NH3-N values can be toxic to fish, but in small concentrations, it could serve as nutrients for excessive growth of algae [27].

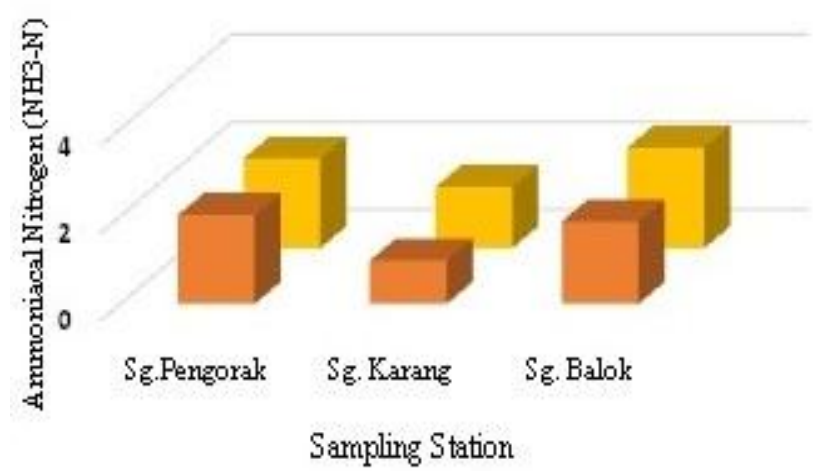

$=24$ Februari $2017=30-\mathrm{Apr}-17$

Fig. 8: The distribution of Ammoniacal Nitrogen $(\mathrm{NH} 3-\mathrm{N})(\mathrm{mg} / \mathrm{L})$ at Kuantan River, Pahang, Malaysia

\subsubsection{Turbidity (TUR) Level}

The turbidity of three sampling stations varies from $9.56 \mathrm{NTU}$ to 21.21 NTU (24 February 2017) and 13.27 NTU to 21.44 NTU (30 April 2017) or an average of 16.37 NTU and 16.97 NTU, the highest (21.44 NTU) at Pengorak River and the lowest (9.56 NTU) at Sungai Balok (Fig. 9). Overall, turbidity level is higher at Pengorak River compared others stations. Comparatively the highest turbidity value was recorded at Pengorak River during both times. According to International Standards, the acceptable turbidity of water for domestic use ranges from 5-25 NTU (Class I) [3]. The turbidity values of Pengorak River are higher than the turbidity values of Balok River and Karang River caused by the industrial development near the Pengorak River will increased the pollutant inputs and triggered the level of deteriorated the water quality [28-30]. Land use development in construction (residential, factory and tourism structure) which increase the chances for runoff and erosion. This leads to an increase in runoff rates, causing cliff erosion and increased turbidity in river basin. Increased in the velocity and volume of water will also increase the rate of the erosion and this situation will increase the amount of suspended solid, water turbidity of river and the river became more shallow, give negative impact on the benthic ecosystem and the flora and fauna in the area around this river $[25,31]$ and reducing the water quality level.

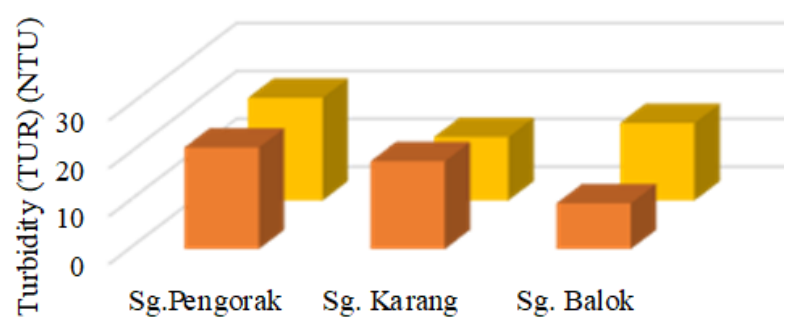

$$
\begin{gathered}
\text { Sampling Station } \\
\text { 24 Februari } 2017=30-\mathrm{Apr}-17
\end{gathered}
$$

Fig. 9: The distribution of turbidity (NTU) at Kuantan River, Pahang Malaysia

\subsubsection{Total Suspended Solid (TSS)}

Soil erosion and deposited of sediment caused by the industrialization and residential resulted to be some of the main sedimentation 
problems and water damage problems at Kuantan River [11]. Kuantan River is also affected by the intertidal monsoon seasons.

The increased of velocity and flow of water river will brings the high loads of TSS as well as other contaminants COD. The adverse effects duet to the hydrological and water quality changes includes damage to the plant communities and aquatic ecosystems as well as increased sedimentation rates. The distribution of TSS (mg/L) at Kuantan River for 24 February and 30 April 2017 which highest values especially on February compared April at all stations. Although there was variability in TSS concentrations, in general, the concentration of TSS increased in going from the upstream stations to the downstream stations. With respect to TSS concentration, all stations were classified as Class II (24 February) and Class I (30 April) according to the NWQS classifications (Table 2). The TSS values range from 20.74 to $52.46 \mathrm{mg} / \mathrm{L}$ (24 February), the highest was recorded at Balok River and the lowest at Sungai Karang. Besides that, the TSS values range from 11.00 to $22.72 \mathrm{mg} / \mathrm{L}$ (30 April), the highest was recorded at Karang River and the lowest at Balok River (Fig. 10).

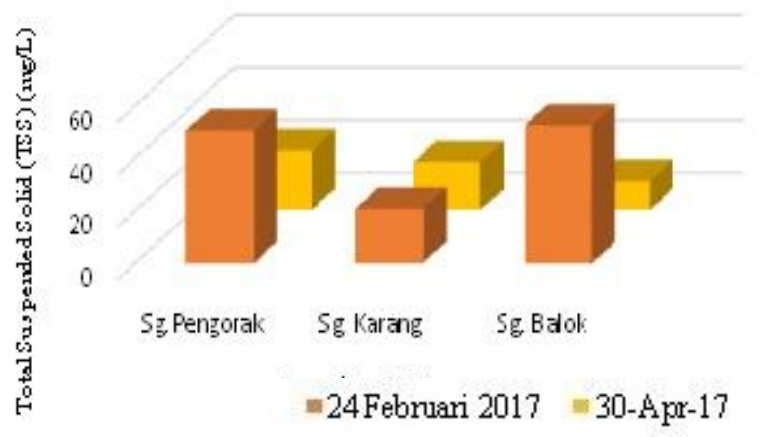

Fig. 10: The distribution of TSS (mg/L) at Kuantan River, Pahang, Malaysia

\subsubsection{Chemical Oxygen Demand (COD)}

The main point sources of higher the concentration of COD around Kuantan River Basin due to the increasing of decomposition of organic materials and inorganic contaminants from industrialization, urbanization and residential areas especially near the sampling stations.

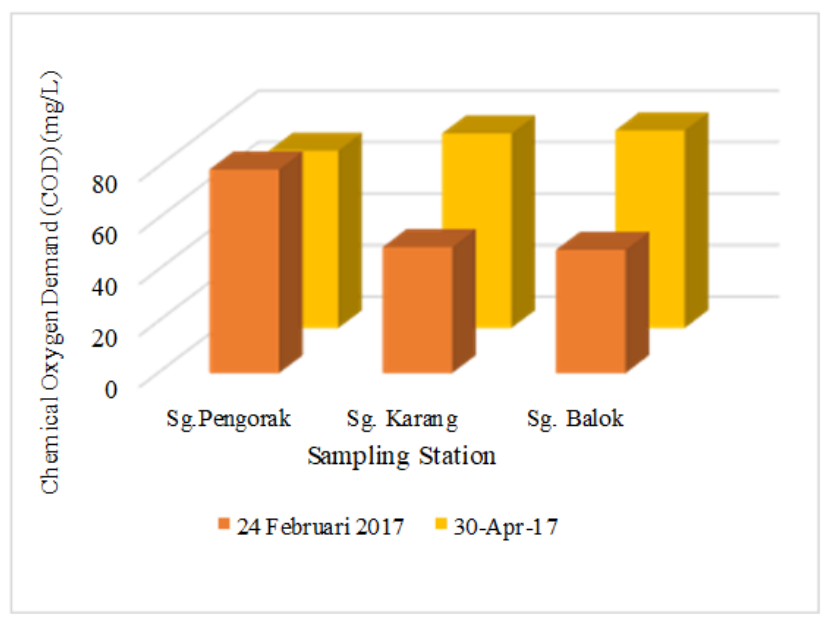

Fig. 11: The distribution of COD $(\mathrm{mg} / \mathrm{L})$ at Kuantan River, Pahang, Malaysia

The ranges of COD values were from 47.89 to $79.11 \mathrm{mg} / \mathrm{L}$ ( 24 February) and from 68.89 to $76.78 \mathrm{mg} / \mathrm{L}$ (30 April) (Fig. 11). The highest concentration had a value of $79.11 \mathrm{mg} / \mathrm{L}$ was recorded at Pengorak River during the first sampling and $76.78 \mathrm{mg} / \mathrm{L}$ at Balok
River for second sampling, while the lowest values, $47.89 \mathrm{mg} / \mathrm{L}$ at Balok River and $68.89 \mathrm{mg} / \mathrm{L}$ respectively. The average COD concentration in the Kuantan River is $58.7 \mathrm{mg} / \mathrm{L}$ (24 February) and $73.7 \mathrm{mg} / \mathrm{L}$ (30 April), and this value was classified as Class IV of the NWQS classification (Fig. 11). Besides that, improper sanitation in local villages, resort and camp near the stations might bring extra biological loading into the river, thus increase the level of COD values. Therefore, a pre-treatment must be treat the wastewater before being discharged as to reduce the concentration of COD.

\subsubsection{Biochemical Oxygen Demand (BOD)}

The biochemical oxygen demand (BOD) of the river was ranging between 0.52 and $0.57 \mathrm{mg} / \mathrm{L}$ (24 February) and from 0.42 to $0.71 \mathrm{mg} / \mathrm{L}$ (30 April). The highest BOD was recorded in the Pengorak River, whereas the lowest was recorded at Balok River (Fig. 12). The concentrations of BOD varied from 0.42 to 0.71 which are considered low but the BOD concentration continuously will increase if the natural plant decaying process and other contributors that increase the total nutrient in water bodies such as fertilizer, construction effluent, animal farm and septic system [32]. Basically, the BOD concentration is directly associated with DO concentrations. When high value of BOD showed declining in DO. The average BOD concentrations in all stations were classified in class I based on NQWS classification this is considered there not polluted areas and the practically no treatment necessary. However, the prevention strategies very important for controlling the pollutants materials in Kuantan River.

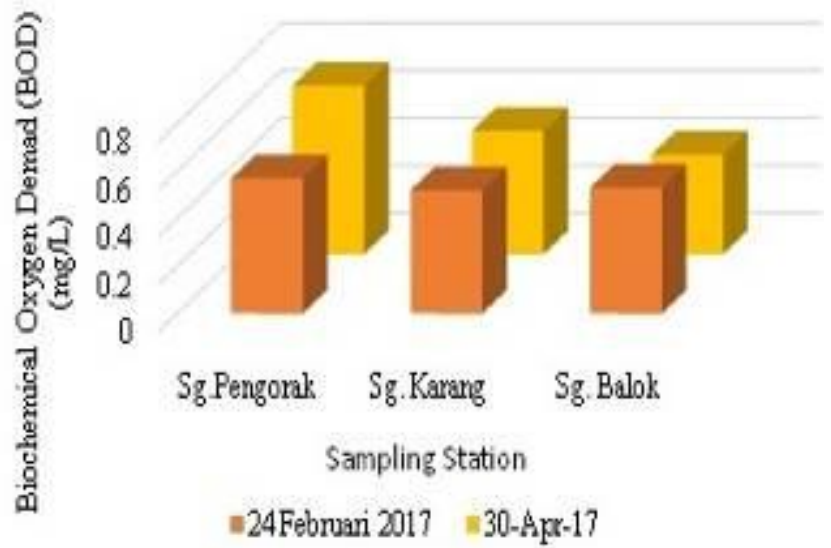

Fig. 12: The distribution of BOD (mg/L) at Kuantan River, Pahang, Malaysia

\subsubsection{Dissolve Oxygen (DO)}

The DO concentration in Sungai Kuantan ranges from 4.59 to 5.35 $\mathrm{mg} / \mathrm{L}$ (24 February) and 1.28 to $5.37 \mathrm{mg} / \mathrm{L}$ (30 April). The lowest DO was recorded at Pengorak River which indicates that there was highly deoxygenated [33]. While, the highest value was at Karang River in the middle stream area (Fig. 13). These results are within the standard acceptable levels of NWQS for Malaysian rivers, which are more than $3 \mathrm{mg} / \mathrm{L}$ as well as categorized under class II. Based on the DO level in Kuantan River proved there is adequate for the planktons to survive and to do various physiological activities because DO is consumed by the degradation of organic matter in water. The waste discharge which flow out from industrial is one another factor affected the low DO value around catchments areas. The DO basically dissolve in water by diffusion process from the atmosphere and as a product of photosynthesis by algae and plants. The excessive growth of algae can over-saturate (greater than $100 \%$ saturation) the water with DO and DO concentration is typically low as there is no mechanism to replace oxygen that is consumed by respiration and decomposition. 


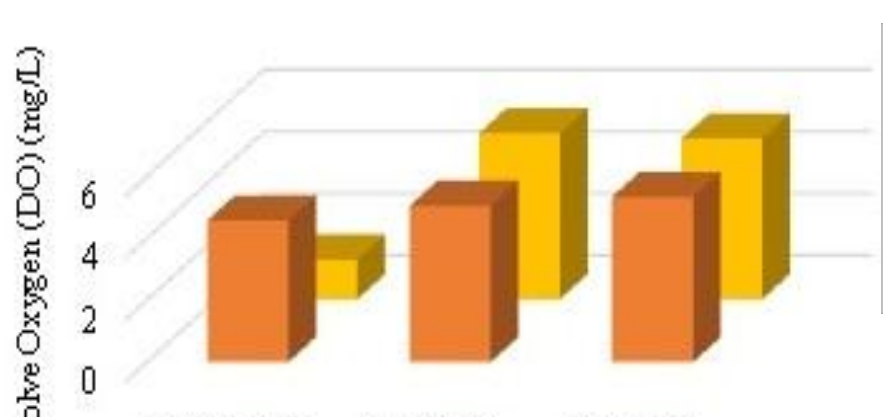

Sg.Pengorak Sg.Karang Sg.Balok SamplingStation

$=24 \mathrm{Februari} 2017=30-\mathrm{Apr}-17$

Fig. 13: The distribution of DO $(\mathrm{mg} / \mathrm{L})$ at Kuantan River, Pahang, Malaysia

\subsubsection{PH Value}

$\mathrm{pH}$ values showed different values between two times sampling in which more alkaline values during 30 April compared 24 February in higher average values of 8.2 are obtained at Balok River in the downstream areas whereas the lowest average values of 6.2 is obtained at Karang River in the middle stream areas (Fig. 14). Generally, the $\mathrm{pH}$ concentration value will increase when the photosynthetic algae activities that consume carbon dioxide dissolved in water [21]. Overall, the range of $\mathrm{pH}$ from 6.5 to 9 is mainly appropriate for aquatic life in the river. Therefore, the suitable $\mathrm{pH}$ value very important to maintain the aquatic ecosystem within this range because high and low $\mathrm{pH}$ can be destructive in nature [34].

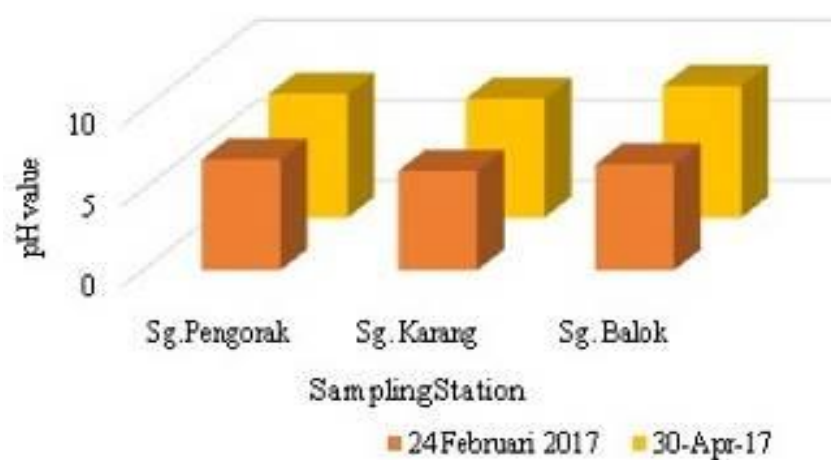

Fig. 14: The distribution of $\mathrm{pH}$ value at Kuantan River, Pahang, Malaysia

\section{Statistical Analysis}

From the regression analysis, it shows that the pollutant loads came from dilution and not only from erosion but from variety of factors such as anthropogenic and climate changes factors. Relatively, there is a natural correlation between the river discharge, rainfall intensity and TSS. Based on hydrological theory, the river discharge rate is one of a factor-affected mobility or concentration of TSS, the higher the velocity, the higher the amount of sediment production [35]. The relationship between discharge and rainfall showed a significant correlation $\left(\mathrm{R}^{2}=0.068\right)($ Fig. 15) and it is proved each feeder river at Kuantan River is not strongly significant relationship between rainfall intensity and Q but more depending on others factors (anthropogenic, geomorphology and climate changes factors).

The quality of the inflowing water from each feeder river to the lake is a function of the pollutant sources. The above criteria show that pollution sources were carried during rainfall through water runoff along the different land use from the upstream into Sungai Pahang.

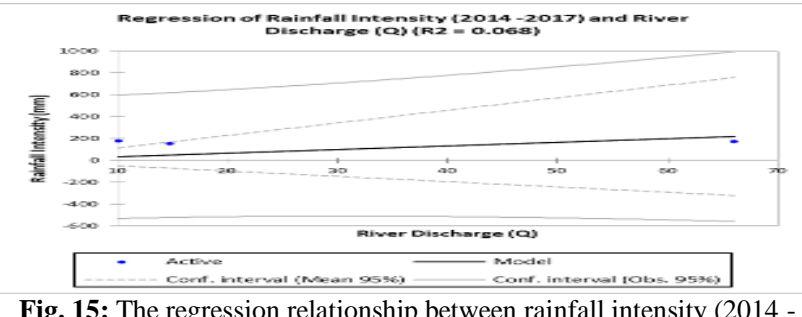

Fig. 15: The regression relationship between rainfall intensity (2014 2017) and river discharge at Sungai Pahang, Pahang, Malaysia

The hydrological characteristic at Kuantan River depends on the intertidal monsoon seasons. The increased of velocity and flow of river will brings the high loads of TSS and effected to the DO, BOD, TSS, TUR concentration as well as other contaminants such as ammoniacal. The leave-one-out method or input importance analyses were carried out to determine significant water quality parameters with river discharge (Table 4 and Table 5). The stream flow from three Feeder Rivers (sampling stations) to Kuantan River was relatively high during wet season than dry season, ranging from $10.1 \mathrm{~m}^{3} / \mathrm{s}$ to 66.63 $\mathrm{m}^{3} / \mathrm{s}$ (24 February) and $10.07 \mathrm{~m}^{3} / \mathrm{s}$ to $65.41 \mathrm{~m}^{3} / \mathrm{s}$ (30 April). Recently, the flow of water river has been shown to affect the geomorphology of the discharge (higher average downstream discharge and lower average upstream discharge) and the peak flow at the downstream parts exceeds than the upstream flow threshold [36-37]. The lowest stream flow rate was recorded of Feeder River as it was a small catchment, the linear relationship analysis showed the closed correlation of TUR $(\mathrm{R}=$ $0.99)$ and $\mathrm{DO}(\mathrm{R}=0.84)$ than other variables during 24 February, TSS $(\mathrm{R}=0.95), \mathrm{pH}(\mathrm{R}=0.90)$ and BOD $(\mathrm{R}=0.81)$ during 30 April. Besides that, there are high significant relations of discharge with TUR $\left(\mathrm{R}^{2}=0.0 .974\right)$ and $\mathrm{DO}\left(\mathrm{R}^{2}=0.70\right)$ during February 2017 and TSS $\left(\mathrm{R}^{2}=0.90\right), \mathrm{pH}\left(\mathrm{R}^{2}=0.70\right)$ and BOD $\left(\mathrm{R}^{2}=0.66\right)$. This high correlated relationship between $\mathrm{Q}$ and TUR, DO, TSS, pH and BOD. The highest concentration of DO in river water depends on the velocity of water, the velocity depends on the intensity of rainfall. The high rate of speed and volume of water, the strong erosion rates [36, 38] and the speed of water flows is the main factor which effected the capacity of concentration of DO.

Soil erosion and deposited of sediment caused by the agricultural, farming land, industrial and residential resulted to be some of the sedimentation problems (TSS and TUR) and water deterioration problems (TUR, DO, TSS, $\mathrm{pH}$ and BOD) at Kuantan River. The increasing suspended sediment loading river basins could lead to increased turbidity, high alkali content in water, emission of unpleasant odors, water discolorations, shallow flow and reduced penetration of sunlight negative effect to the process of photosynthesis by aquatic plants. Consequently, aquatic organisms would be impacted by the lack of oxygen and unbalanced $\mathrm{pH}$ of the water $[8,39,40]$.

Table 4: Input importance variables in linear relationship to predict river discharge (Q) on 24 February at Kuantan River Basin, Pahang, Malaysia, 2017

\begin{tabular}{|c|c|c|c|c|c|c|c|c|}
\hline $\begin{array}{l}\text { Varia- } \\
\text { bles }\end{array}$ & Q & TSS & $\begin{array}{c}\mathrm{BO} \\
\mathrm{D}\end{array}$ & $\begin{array}{c}\mathrm{CO} \\
\mathrm{D}\end{array}$ & $\mathrm{Ph}$ & $\begin{array}{c}\mathrm{TU} \\
\mathrm{R}\end{array}$ & $\begin{array}{c}\text { NH3- } \\
\mathrm{N}\end{array}$ & DO \\
\hline Q & 1.00 & 0.48 & $\begin{array}{c}- \\
0.40\end{array}$ & $\begin{array}{c}- \\
0.59\end{array}$ & 0.01 & $\begin{array}{c}- \\
0.99\end{array}$ & 0.31 & 0.84 \\
\hline TSS & 0.48 & 1.00 & 0.61 & 0.43 & 0.88 & $\overline{0}-\overline{33}$ & 0.98 & $\begin{array}{c}- \\
0.08 \\
\end{array}$ \\
\hline BOD & $\begin{array}{c}- \\
0.40 \\
\end{array}$ & 0.61 & 1.00 & 0.98 & 0.92 & 0.54 & 0.75 & $\begin{array}{c}- \\
0.84 \\
\end{array}$ \\
\hline COD & $\begin{array}{c}- \\
0.60\end{array}$ & 0.43 & 0.98 & 1.00 & 0.80 & 0.71 & 0.59 & $\begin{array}{c}- \\
0.94\end{array}$ \\
\hline $\mathrm{pH}$ & 0.01 & 0.88 & 0.92 & 0.80 & 1.00 & 0.16 & 0.95 & $\begin{array}{c}- \\
0.55\end{array}$ \\
\hline TUR & $\overline{-}$ & $\overline{-}$ & 0.54 & 0.71 & 0.16 & 1.00 & -0.15 & $\begin{array}{c}- \\
0.91\end{array}$ \\
\hline
\end{tabular}




\begin{tabular}{|c|c|c|c|c|c|c|c|c|}
\hline NH3-N & 0.31 & 0.98 & 0.75 & 0.59 & 0.95 & $\begin{array}{c}- \\
0.15\end{array}$ & 1.00 & $\begin{array}{c}- \\
0.27\end{array}$ \\
\hline DO & 0.84 & $\begin{array}{c}- \\
0.08\end{array}$ & $\begin{array}{c}- \\
0.84\end{array}$ & $\begin{array}{c}- \\
0.94\end{array}$ & $\overline{-}-\overline{55}$ & $\begin{array}{c}- \\
0.91\end{array}$ & -0.27 & 1.00 \\
\hline
\end{tabular}

\begin{tabular}{|c|c|c|c|c|c|c|}
\hline & TSS & BOD & COD & Ph & NH3-N & DO \\
\hline $\mathrm{R}^{\mathbf{2}}$ & $\mathbf{0 . 7 7}$ & $\mathbf{0 . 8 4}$ & $\mathbf{0 . 6 5}$ & 1.00 & $\mathbf{0 . 9 1}$ & 0.30 \\
\hline $\mathrm{F}$ & 11.89 & 222.48 & 22.60 & 197.94 & 17.24 & 617.38 \\
\hline $\mathrm{Pr}>\mathrm{F}$ & 0.08 & 0.004 & 0.04 & 0.01 & 0.05 & 0.002 \\
\hline
\end{tabular}

\begin{tabular}{|c|c|c|c|c|c|c|c|}
\hline & TSS & BOD & COD & Ph & TUR & NH3-N & DO \\
\hline $\mathrm{R}^{2}$ & 0.23 & 0.16 & 0.35 & 0.00 & $\mathbf{0 . 9 7}$ & 0.10 & $\mathbf{0 . 7 0}$ \\
\hline $\mathrm{F}$ & 4.27 & 2.66 & 1.49 & 2.84 & 0.87 & 3.35 & 3.52 \\
\hline Pr> F & 0.18 & 0.24 & 0.35 & 0.23 & 0.45 & 0.21 & 0.20 \\
\hline
\end{tabular}

Table 5: Input importance variables in linear relationship to predict river discharge (Q) on 30 April 2017 at Kuantan River Basin, Pahang, Malaysia, 2016

\begin{tabular}{|c|c|c|c|c|c|c|c|c|}
\hline $\begin{array}{c}\text { Varia- } \\
\text { bles }\end{array}$ & Q & TSS & $\begin{array}{c}\text { NH3- } \\
\text { N }\end{array}$ & DO & $\begin{array}{c}\mathrm{CO} \\
\mathrm{D}\end{array}$ & $\mathrm{Ph}$ & $\begin{array}{c}\mathrm{BO} \\
\mathrm{D}\end{array}$ & $\begin{array}{c}\mathrm{TU} \\
\mathrm{R}\end{array}$ \\
\hline Q & 1.00 & 0.95 & 0.66 & 0.53 & 0.68 & 0.90 & $\begin{array}{c}- \\
0.81\end{array}$ & $\begin{array}{c}- \\
0.24\end{array}$ \\
\hline TSS & $\begin{array}{c}- \\
0.95\end{array}$ & 1.00 & -0.40 & $\begin{array}{c}- \\
0.77 \\
\end{array}$ & $\begin{array}{c}- \\
0.87 \\
\end{array}$ & $\begin{array}{c}- \\
0.72 \\
\end{array}$ & 0.95 & 0.53 \\
\hline NH3-N & 0.66 & $\begin{array}{c}- \\
0.40 \\
\end{array}$ & 1.00 & $\begin{array}{c}- \\
0.29 \\
\end{array}$ & $\begin{array}{c}- \\
0.11 \\
\end{array}$ & 0.92 & $\begin{array}{c}- \\
0.10 \\
\end{array}$ & 0.57 \\
\hline DO & 0.53 & $\begin{array}{c}- \\
0.77 \\
\end{array}$ & -0.29 & 1.00 & 0.98 & 0.10 & $\begin{array}{c}- \\
0.93\end{array}$ & 0.95 \\
\hline COD & 0.68 & $\begin{array}{c}- \\
0.87 \\
\end{array}$ & -0.11 & 0.98 & 1.00 & 0.28 & $0 . \overline{-}$ & $\begin{array}{c}- \\
0.88 \\
\end{array}$ \\
\hline $\mathrm{pH}$ & 0.90 & $\begin{array}{c}- \\
0.72\end{array}$ & 0.92 & 0.10 & 0.28 & 1.00 & $\begin{array}{c}- \\
0.47 \\
\end{array}$ & 0.22 \\
\hline BOD & $\begin{array}{c}- \\
0.81 \\
\end{array}$ & 0.95 & -0.10 & $\begin{array}{c}- \\
0.93 \\
\end{array}$ & $\begin{array}{c}- \\
0.98 \\
\end{array}$ & $\begin{array}{c}- \\
0.47 \\
\end{array}$ & 1.00 & 0.76 \\
\hline TUR & $\begin{array}{c}- \\
0.24\end{array}$ & 0.53 & 0.57 & $\begin{array}{c}- \\
0.95\end{array}$ & $\begin{array}{c}- \\
0.88\end{array}$ & 0.22 & 0.76 & 1.00 \\
\hline
\end{tabular}

Table 7: Input importance variables in linear relationship to predict water quality index (WQI) on 30 April 2017 at Kuantan River Basin, Pahang, Malaysia, 2016

\begin{tabular}{|c|c|c|c|c|c|c|c|}
\hline Variables & WQI & TSS & NH3-N & DO & COD & Ph & BOD \\
\hline WQI & 1.00 & 0.48 & -0.99 & 0.19 & 0.01 & -0.96 & 0.19 \\
\hline TSS & 0.48 & 1.00 & -0.40 & -0.77 & -0.87 & -0.72 & 0.95 \\
\hline NH3-N & $\mathbf{- 0 . 9 9}$ & -0.40 & 1.00 & -0.29 & -0.11 & 0.92 & -0.010 \\
\hline DO & 0.19 & -0.77 & -0.29 & 1.00 & 0.98 & 0.10 & -0.93 \\
\hline COD & 0.01 & -0.87 & -0.11 & 0.98 & 1.00 & 0.28 & -0.98 \\
\hline pH & $\mathbf{- 0 . 9 6}$ & -0.72 & 0.92 & 0.10 & 0.28 & 1.00 & -0.47 \\
\hline BOD & 0.19 & 0.95 & -0.10 & -0.93 & -0.98 & -0.47 & 1.00 \\
\hline
\end{tabular}

\begin{tabular}{|c|c|c|c|c|c|c|}
\hline & TSS & NH3-N & DO & COD & Ph & BOD \\
\hline $\mathrm{R}^{\mathbf{2}}$ & 0.23 & $\mathbf{0 . 9 9}$ & 0.04 & 0.00 & $\mathbf{0 . 9 2}$ & 0.04 \\
\hline $\mathrm{F}$ & 27.84 & 40.95 & 8.92 & 743.68 & 486.26 & 43.12 \\
\hline $\mathrm{Pr}>\mathrm{F}$ & 0.03 & 0.02 & 0.10 & 0.001 & 0.002 & 0.02 \\
\hline
\end{tabular}

\section{Conclusion}

This study showed the water quality and quantity status of the 3 stations in the Kuantan River were unstable level but not critically deterioration and this study detected the main causes of this problem happened.

These problems in Kuantan River caused by the geomorphology and anthropogenic factors such as urbanization, industrialization and bank erosion along the river basin. The prevention and the fast step towards must be implement by the authorities and the communities to cover these environmental problems. Besides that, the law enforcement is expected to be carried out especially to industrialization activists around Kuantan River decrease the negative impact on the environment and society. $(\mathrm{R}=0.81)$ and $\mathrm{NH}_{3}{ }^{-} \mathrm{N}\left(\mathrm{R}^{2}=0.95\right)$ value in the Kuantan River was higher correlated to WQI for 24 February and $\mathrm{NH}_{3}{ }^{-} \mathrm{N}(\mathrm{R}=0.995)$, $\mathrm{pH}(\mathrm{R}=0.96)$ (30 April), TSS $\left(\mathrm{R}^{2}=0.88\right)$, BOD $\left(\mathrm{R}^{2}=0.84\right)$, COD $\left(\mathrm{R}^{2}=0.65\right)$ and $\mathrm{NH}^{3-} \mathrm{N}\left(\mathrm{R}^{2}=0.91\right)$ during 24 February and $\mathrm{NH}^{3-} \mathrm{N}$ $\left(\mathrm{R}^{2}=0.99\right)$ and $\mathrm{pH}\left(\mathrm{R}^{2}=0.92\right)$ (Table 6 and Table 7).

Improper sanitation systems at the local villages, industrial, agricultural, sewage disposal and residential could result in extra biological loading into the Kuantan River, thus increasing the BOD, COD, $\mathrm{pH}$ and $\mathrm{NH}_{3}{ }^{-} \mathrm{N}$ values. In terms of COD, the Sungai Kuantan water is suitable for the support of aquatic life as well as for other purposes. The value of BOD and COD were increased with increase in the pollution load. The high concentration of $\mathrm{NH}_{3}$ $\mathrm{N}$ during both time coincided with the high TSS and TUR content. All the water samples collected were found to contain less ammoniacal nitrogen than the maximum permissible limit set by the World Health Organization. From $\mathrm{pH}$ values correlated to WQI during 30 April proved the acidity of natural river ecosystems has been reported to be in the range of 4.5-6.5.

Low $\mathrm{pH}$ values are found in natural waters which are rich in organic matter and this was observed especially at Karang River and Sungai Balok where there were observed especially abundant decaying aquatic weeds which caused lowering in the lowering in the $\mathrm{pH}$ values as a result of decomposition.

Table 6: Input importance variables in linear relationship to predict water quality index (WQI) on 24 February at Kuantan River Basin, Pahang, Malaysia, 2017

\begin{tabular}{|c|c|c|c|c|c|c|c|}
\hline Variables & WQI & TSS & BOD & COD & Ph & NH3-N & DO \\
\hline WQI & 1.00 & -0.88 & -0.92 & -0.81 & -1.00 & -0.95 & 0.55 \\
\hline TSS & $\mathbf{- 0 . 8 8}$ & 1.00 & 0.61 & 0.43 & 0.88 & 0.98 & -0.08 \\
\hline BOD & $\mathbf{- 0 . 9 2}$ & 0.61 & 1.00 & 0.98 & 0.92 & 0.75 & -0.84 \\
\hline COD & $\mathbf{- 0 . 8 1}$ & 0.43 & 0.98 & 1.00 & 0.80 & 0.59 & -0.94 \\
\hline pH & -1.00 & 0.88 & 0.92 & 0.80 & 1.00 & 0.95 & -0.55 \\
\hline NH3-N & $\mathbf{- 0 . 9 5}$ & 0.98 & 0.75 & 0.59 & 0.95 & 1.00 & -0.27 \\
\hline DO & 0.55 & -0.08 & -0.84 & -0.94 & -0.55 & -0.27 & 1.00 \\
\hline
\end{tabular}

\section{Acknowledgement}

The author would like to thank KPM for providing financial support for this research on the RAGS 2015 Siasatan Penghasilan Sedimen Grant RAGS/ 1/2015 /WAB05/ UNISZA / 02/1, FRGS/1/2016/Wab05/UNISZA/03/1, Department of Irrigation and Drainage Malaysia for the secondary data and East Coast Environmental Research Institute (ESERI), Universiti Sultan ZainalAbidin (UNISZA) give permission to use research facilities and supporting in this research.

\section{References}

[1] Aziz NAA, Toriman ME, Gasim MB, Muftah S, Barggig A \& Kamarudin MKA (2017), Water Quality Deterioration in Artificial Lake: Their Impact and Sources. International Journal on Advanced Science, Engineering and Information Technology, 7(1): 49-56.

[2] Wahab NA, Kamarudin MKA, Anuar A, Ata FM, Sulaiman NH, Baharim NB \& Muhammad NA (2017), Assessments of Lake Profiling On Temperature, Total Suspended Solid (TSS) and Turbidity in The Kenyir Lake, Terengganu, Malaysia. Journal of Fundamental and Applied Sciences, 9(2S): 256-278.

[3] Hammer MJ, MacKichan KA \& Harrison AS (1981), Hydrology and quality of water resources. John Wiley.

[4] Kamarudin, M. K. A., Toriman, M. E., Sulaiman, N. H., Ata, F. M., Gasim, M. B., Muhamad, A., Yusoff, W. A., Mokhtar, M., Amran, M. A., Abd Aziz, N. A. (2015). Classification of tropical river using chemometrics technique: Case study in Pahang River, Malaysia. Malaysian Journal of Analytical Sciences, 19(5), 1001-1018.

[5] Gasim MB, Othman MS \& Tan CC (2005), Total flows contribution of the Tasik Chini Feeder Rivers and its significant water level, Pahang, Malaysia. Proc. 6th ITB-UKM Joint Semi. On Chem, 543547.

[6] Nemerow NL. (1991), Stream, lake, estuary, and ocean pollution. 
[7] Rashid SAA, Gasim MB, Toriman ME, Juahir H, Kamarudin MKA, Azid A \& Aziz NAA )2013), Water quality deterioration of Jinjang River, Kuala Lumpur: Urban risk case water pollution. The Arab World Geographer, 16(4): 349-362.

[8] Kamarudin MKA, Toriman ME, Syed ASM, Idris MH, Jamil NR \& Gasim MB (2009), Temporal variability on lowland river sediment properties and yield. American Journal of Environmental Sciences, 5(5): 657-663.

[9] Gasim MB, Toriman MEH, Abas A, Islam M, \& Tan CC. (2008). Water quality of several feeder rivers between two seasons in Tasik Chini, Pahang. Sains Malaysiana, 37(4), 313-321.

[10] Kamarudin, M. K. A., Toriman, M. E., Rosli, M. H., Juahir, H., Aziz, N. A. A., Azid, A., ... \& Sulaiman, W. N. A. (2015). Analysis of meander evolution studies on effect from land use and climate change at the upstream reach of the Pahang River, Malaysia. Mitigation and Adaptation Strategies for Global Change, 20(8), 1319 1334.

[11] Wahab NA, Kamarudin MKA, Gasim MB, Umar R, Ata FM \& Sulaiman NH (2016), Assessment of total suspended sediment and bed sediment grains in upstream areas of Lata Berangin. Terengganu. International Journal on Advanced Science, Engineering and Information Technology, 6(5),757-763.

[12] Toriman ME, Kamarudin MKA, Idris MH, Gasim MB \& Jamil NR (2008), Masalah sedimentasi dan penyelesaiannya melalui kaedah pengurusan persekitaran: satu kajian kes di Sungai Chini, Pahang. e- BANGI: Jurnal Sains Sosialdan Kemanusiaan, 3(3): 14.

[13] Sujaul I.M, Barzani GM., Ismail BS, Sahibin AR., \& Ekhwan TM (2012). Estimation of the rate of soil erosion in the tasik chini catchment, Malaysia using the RUSLE model integrated with the GIS. Australian Journal of Basic and Applied Sciences, 6(12), 286296.

[14] Thornthwaite CW, \& Hare FK (1965). The loss of water to the air. In Agricultural Meteorology (pp. 163-180). American Meteorological Society.

[15] Oki T, Musiake K., Matsuyama H., \& Masuda K (1995), Global atmospheric water balance and runoff from large river basins. Hydrological Processes, 9(5-6), 655-678.

[16] Shuhaimi-Othman M., Lim EC, \& Mushrifah I. (2007), Water quality changes in Chini Lake, Pahang, West Malaysia. Environmental monitoring and assessment, 131(1-3), 279-292.

[17] Burn DH., \& McBean EA. (1985). Optimization modeling of water quality in an uncertain environment. Water Resources Research, 21(7), 934-940.

[18] Avvannavar SM, \& Shrihari S (2008). Evaluation of water quality index for drinking purposes for river Netravathi, Mangalore, South India. Environmental Monitoring and Assessment, 143(1), 279-290.

[19] Gasim MB, Toriman MEH, Abas A., Islam M, \& Tan CC. (2008) Water quality of several feeder rivers between two seasons in Tasik Chini, Pahang. Sains Malaysiana, 37(4), 313-321

[20] Alam MJ, Islam MR, Muyen Z, Mamun M, \& Islam S (2007), Water quality parameters along rivers. International Journal of Environmental Science \& Technology, 4(1), 159-167.

[21] Gandaseca S, Rosli N, Ngayop J, \& Arianto CI. (2011). Status of water quality based on the physico-chemical assessment on river water at Wildlife Sanctuary Sibuti Mangrove Forest, Miri Sarawak. American Journal of Environmental Sciences, 7(3), 269.

[22] Al-Mamun A, \& Zainuddin Z. (2013), Sustainable river water quality management in Malaysia. IIUM Engineering Journal, 14(1).

[23] Grayson RB, Finlayson BL, Gippel CJ, \& Hart BT. (1996), The potential of field turbidity measurements for the computation of total phosphorus and suspended solids loads. Journal of Environmental Management 47(3): 257-267.

[24] Othman Jaafar M, Toriman E, Mastura SS, Gazim MB, Lun PI Abdullah P, Kamarudin M.K.A, \& Aziz NAA (2010), Modeling the impacts of ringlet reservoir on downstream hydraulic capacity of Bertam River using XPSWMM in cameron highlands, Malaysia. Research Journal of Applied Sciences, 5(2), 47-53.

[25] Mikhailov VN, Kravtsova VI \& Magritskii DV (2004), Specific Features of Development of the Modern Sulak River Delta. Water Resources, 31(2): 133-147.

[26] Ata FM, Toriman MET \& Kamarudin MKA (2015). Impact of interception on infiltration and soil moisture in dipterocarp forest and oil palm plantations in Tasik Chini, Pahang. Malaysian Journal of Analytical Sciences, 19(5): 1084-1092.

[27] Corwin DL, Loague K, and Ellsworth TR (1999) Advanced information technologies for assessing nonpoint source pollution in the Vadose Zone: conference overview, Journal of Environmental
Quality, vol. 28, no. 2, pp. 357-365, View at Google Scholar View at Scopus.

[28] Jindal R, \& Sharma C (2011). Studies on water quality of Sutlej River around Ludhiana with reference to physicochemical parameters. Environmental monitoring and assessment, 174(1), 417-425.

[29] Sánchez E., Colmenarejo MF, Vicente J, Rubio A., García MG, Travieso L, \& Borja R. (2007). Use of the water quality index and dissolved oxygen deficit as simple indicators of watersheds pollution. Ecological Indicators, 7(2), 315-328.

[30] Suratman S, Sailan MM, Hee YY., Bedurus EA., \& Latif MT (2015), A preliminary study of water quality index in Terengganu River basin, Malaysia. Sains Malaysiana, 44(1), 67-73.

[31] Toriman ME, Pereira JJ, Gasim MB, Sharifah Mastura SA, \& Aziz NAA. (2009), Issues of climate change and water resources in peninsular Malaysia: The case of north Kedah. The Arab World Geographer, 12(1-2), 87-94

[32] Gasim MB, Ismail BS, Wan NA., Muhammad IY, \& Marlia MH (2005), Water quality assessment of the Semenyih River basin Selangor, Malaysia. J Biosci Malays, 16(1), 87-95

[33] Yaakub N, Raoff MNA, Haris MN, Halim AAA, \& Kamarudin MKA. (2017), Water Quality Assessment of the Rivers in Bauxite Mining Area at Kuantan Pahang. Journal of Fundamental and Applied Sciences, 9(2S), 761-776.

[34] Noraini R, Seca G, Johan I, \& Mohd IJ (2010), Comparative study of water quality at different peat swamp forest of BatangIgan, Sibu Sarawak. American Journal of Environmental Sciences, 6(5), 416421.

[35] Toriman ME, Hashim N, Kamarudin MKA, Hassan AJ, Gasim MB, Muhamad A, and Aziz NAA (2015), “Assessment of water salinity model using hydrodynamic numerical modelling in estuary of Selangor River, Malaysia," Malaysian Journal of Analytical Sciences, vol. 19, pp. 1109-1119

[36] Kamarudin MKA., Toriman M.E, Idris M, Juahir H, Azid, A, Gasim MB, Ismail A. (2016). Environmental Management on Natural Lake Using Sediment and Hydrology Hydraulic Models. Malaysian Journal of Applied Sciences, 1(2), 9-26.

[37] Jaafar O, Toriman MEH, Idris MH, Mastura SS, Juahir H. H, Aziz NAA, Kamarudin, MKA, Jamil NR (2010), Study of water leveldischarge relationship using artificial neural network (ANN) in Sungai Gumum, TasikChini Pahang Malaysia. Research Journal of Applied Sciences, 5(1), 20-26.

[38] Toriman ME, Kamarudin MKA, Aziz NAA., Din HM, Ata FM, Abdullah NM, Abdullah NW (2012), Pengurusan sedimen terhadap sumber air bersepadu: satu kajian kes di Sungai Chini, Pekan Pahang. e-BANGI. Jurnal Sains Sosial dan Kemanusiaan, 7(1): 267 283.

[39] Azid, A., Juahir, H., Toriman, M. E., Endut, A., Kamarudin, M. K. A., Rahman, A., \& Nordin, M. (2015). Source apportionment of air pollution: A case study in Malaysia. Jurnal Teknologi, 72(1), 83-88.

[40] Rwoo MA, Juahir H, Roslan NM, Endut A, Kamarudin MKA, \& Amran MA (2017), Assessment of Drinking Water Quality Using Principal Component Analysis and Partial Least Square Discriminant Analysis: A Case Study at Water Treatment Plants, Selangor. Journal of Fundamental and Applied Sciences, 9(2S), 157-173. 